\title{
IMPLEMENTASI KEBIJAKAN SATU MOBIL SATU GARASI PROVINSI DKI JAKARTA
}

\section{(Perda Provinsi DKI Jakarta Nomor 5 Tahun 20 I 4 tentang Transportasi)}

\author{
Wajoerini ${ }^{\mathrm{a}}$, Andarina Aji Pamurti ${ }^{\mathrm{b}}$ \\ aUniversitas Semarang; Jl. Soekarno Hatta; riniwahjoe@gmail.com \\ bUniversitas Semarang; Jl. Soekarno Hatta; andarina.ajip@gmail.com \\ - Artikel diterima: 31/09/21 \\ - Tersedia Online: 31/12/21
}

Info Artikel:

- Artikel Masuk: 31/08/21

\begin{abstract}
ABSTRAK
Kebijakan mengenai kepemilikan kendaraan bermotor disertai dengan kepemilikan garasi telah tertuang Peraturan Daerah (Perda) DKI Jakarta Nomor 5 Tahun 2014 Pasal 140. Namun karena berbagai kendala, peraturan yang terbit pada tahun 2014 belum menunjukkan hasil yang signifikan dalam mengurangi jumlah kendaraan bermotor. Satu diantara metode yang sangat berguna dalam kajian kebijakan adalah Institutional Analysis Development (IAD) yang dikembangkan oleh Elinor Ostrom pada tahun 1994. kebijakan terkait kepemilikan garasi bagi pemilik kendaraan bermotor khusus nya mobil terdapat tumpang tindih dengan kebijakan yang kedudukannnya diatasnya yang saling terkait. kemungkinan terjadinya konflik kepentingan antar stakeholder terkait implementasi sementara itu jika dirinci lebih lanjut, terdapat kemungkinan konflik kepentingan dan potensi yang dapat dikembangkan melalui interaksi antar stakeholer. Masalah yang ada berakar dari ketiadaan aturan teknis dan kurangnya koordinasi antar sektor pemerintahan baik dalam skala nasional maupun lokal (provinsi). Kedua akar masalah tersebut menghasilkan permasalahan yang terjadi saat ini seperti perbedaan peraturan dan kepentingan antar Lembaga. Kemudian belum adanya mekanisme kontrol perizinan dan pengawasan yang terstruktur dan terintegrasi antar Lembaga.
\end{abstract}

Kata Kunci : Kebijakan; Kelembagaan; Stakeholder

\section{ABSTRACT}

The policy regarding motorized vehicle ownership along with garage ownership has been stipulated in DKI Jakarta Regional Regulation (Perda) Number 5 of 2014 Article 140. However, due to various obstacles, the regulations issued in 2014 have not shown significant results in reducing the number of motorized vehicles. One method that is very useful in policy studies is the Institutional Analysis Development (IAD) which was developed by Elinor Ostrom in 1994. The policies related to garage ownership for owners of motorized vehicles, especially cars, overlap with policies whose positions above are interrelated. the possibility of a conflict of interest between stakeholders related to the implementation, meanwhile, if further detailed, there is a possibility of a conflict of interest and the potential that can be developed through interaction between stakeholders. The problem is rooted in the absence of technical regulations and the lack of coordination between government sectors both on a national and local (provincial) scale. These two root causes result in current problems such as differences in regulations and interests between institutions. Then there is no mechanism for licensing control and supervision that is structured and integrated between institutions.

Keyword: Policy; Institutional; Stakeholders

\section{PENDAHULUAN}

Permasalahan transportasi di Indonesia merupakan permasalahan yang tak ada ujungnya khususnya permasalahan transportasi darat yang cukup kompleks. Hal ini dikarenakan transportasi merupakan suatu sistem yang saling berkaitan, maka suatu masalah yang timbul di satu unit ataupun jaringan akan mempengaruhi sistem tersebut. Faktor-faktor yang mempengaruhi timbulnya masalahmasalah pada transportasi darat di Indonesia sangat beragam, antara lain ledakan penduduk, tingginya jumlah kendaraan bermotor, kurangnya kesadaran masyarakat, serta lemahnya penegakan hukum. 
Pertumbuhan penduduk yang tinggi khususnya di kota - kota besar berbanding lurus dengan kepemilikan kendaraan pribadi yang semakin meningkat. Salah satu akibat yang ditimbulkan dari meningkatnya jumlah kendaraan bermotor ialah kemacetan. Kemacetan merupakan permasalahan yang paling mengganggu kenyamanan pengguna transportasi darat. Kemacetan dapat mengurangi efektifitas kerja, memperlambat manusia untuk melakukan aktifitas, meningkatkan polusi udara, dan merupakan pemborosan bahan bakar yang semakin hari semakin menipis. Kemacetan lalu lintas disebabkan ruas-ruas jalan sudah tidak mampu menampung luapan arus kendaraan yang datang serta luasan dari jalan tidak seimbang dengan jumlah kendaraan yang melintas. Hal ini terjadi juga karena pengaruh hambatan samping yang tinggi, sehingga mengakibatkan penyempitan ruas jalan, seperti parkir dibadan jalan, berjualan di trotoar dan badan jalan, dsb. Selain itu juga kemacetan juga sering terjadi akibat manajemen transportasi yang kurang baik.

Dampak lain yang ditimbulkan oleh peningkatan jumlah kendaraan adalah ketersediaan lahan parkir. Terbatasnya lahan parkir membuat pemerintah setempat dituntut untuk mengatur terkait lahan parkir. Fenomena ini terjadi di Kota Jakarta, banyak dijumpai pada perumahan - perumahan dengan parkir kendaraan pribadi yang tidak tertata dengan baik sehingga menyusahkan pergerakan kendaraan yang lain jika melewati jalan tersebut, hal ini dikarenakan tidak adanya lahan parkir pada setiap rumah sehingga kendaraan pribadi khususnya mobil diparkir di depan rumah dengan posisi zig-zag. Permasalahan tersebut memaksa pemerintah Provinsi DKI Jakarta menetapkan aturan mengenai kewajiban pemilik kendaraan bermotor harus punya garasi tertuang dalam Pasal 140 perda tentang transportasi tersebut. Bunyi pasal tersebut yakni sebagai berikut: (1) Setiap orang atau badan usaha pemilik kendaraan bermotor wajib memiliki atau menguasai garasi. (2) Setiap orang atau badan usaha pemilik kendaraan bermotor dilarang menyimpan kendaraan bermotor di ruang milik jalan. (3) Setiap orang atau badan usaha yang akan membeli kendaraan bermotor wajib memiliki atau menguasai garasi untuk menyimpan kendaraannya yang dibuktikan dengan surat bukti kepemilikan garasi dari kelurahan setempat. (4) Surat bukti kepemilikan garasi sebagaimana dimaksud pada ayat (3) menjadi syarat penerbitan Surat Tanda Nomor Kendaraan Bermotor. (5) Ketentuan lebih lanjut mengenai kepemilikan kendaraan bermotor diatur dengan Peraturan Gubernur.

Kebijakan mengenai kepemilikan kendaraan bermotor disertai dengan kepemilikan garasi telah tertuang Peraturan Daerah (Perda) DKI Jakarta Nomor 5 Tahun 2014 Pasal 140. Pemerintah Daerah DKI Jakarta berharap dengan adanya kebijakan ini masyarakat yang semakin banyak menggunakan kendaraan pribadi berpindah ke moda transportasi publik, sehingga kemacetan yang disebabkan banyaknya kendaraan bermotor dapat dihindari. Namun karena berbagai kendala, peraturan yang terbit pada tahun 2014 belum menunjukkan hasil yang signifikan dalam mengurangi jumlah kendaraan bermotor. Dengan demikian tanpa adanya dukungan kebijakan dari pihak lain, kondisi kemacetan akan menjadi masalah yang mengancam dan berlarut-larut.

\section{DATA DAN METODE}

Pendekatan tradisional untuk mengerti kebijakan publik dibagi dalam beberapa tahapan yaitu identifikasi permasalahan, pengaturan agenda, formulasi, adopsi, implementasi dan evaluasi kebijakan. (Koontz, 2003). Mengidentifikasi permasalahan yang menyebabkan kurang optimalnya penerapan kewajiban penyediaan parkir bagi kendaraan baru di Provinsi DKI Jakarta merupakan bagian dari kajian dari kebijakan itu sendiri. Prosesnya membutuhkan langkah kerja yang terstruktur agar tetap memperhatikan kaidah ilmiah dan memberikan hasil yang dapat dipertanggung jawabkan.

Satu diantara metode yang sangat berguna dalam kajian kebijakan adalah Institutional Analysis Development (IAD) yang dikembangkan oleh Elinor Ostrom pada tahun 1994. IAD adalah instrumen yang dapat digunakan untuk mengevaluasi efektivitas kebijakan, menginisiasi perubahan kebijakan dan mendesain intervensi kebijakan baru (Polski \& Ostrom, 1999). IAD adalah analisis yang 
dapat bersifat multi dimensi yang menjelaskan tindakan aktor dalam 3 jenis, yaitu operasional, pilihan bersama dan pilihan konstitusional (Ostrom, 2005). Analisis multi dimensi ini dibutuhkan karena implementasi kebijakan kewajiban penyediaan parkir bagi kendaraan baru di Provinsi DKI Jakarta ini membutuhkan kerja sama dari semua pihak. Kerja sama ini bukan hanya melibatkan lembaga dalam pemerintahan, baik secara vertikal maupun horizontal, namun juga melibatkan pihak swasta dan masyarakat. Metode ini akan membantu memahami situasi sosial yang rumit dan menjabarkannya ke dalam beberapa aspek yang dapat dikelola secara efisien (Polski \& Ostrom, 1999). Oleh karena itu, metode yang digunakan harus mampu mengakomodir keputusan - keputusan yang diambil setiap aktornya.

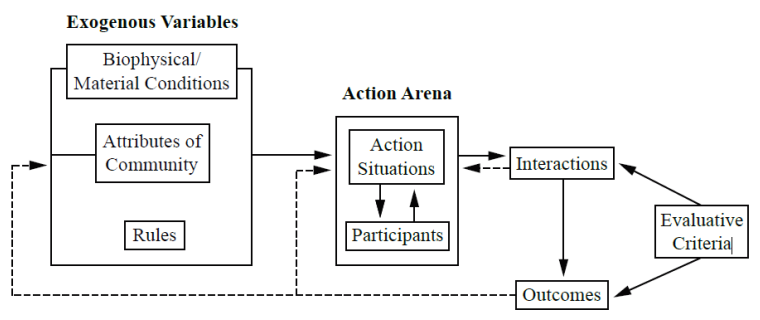

Gambar 1. Kerangka Kerja Analisis Kelembagaan (Ostorm, 2005)

Diagram diatas memperlihatkan bahwa keputusan dari yang diambil oleh setiap aktor tergantung pada partisipasi aktor lainnya dan adanya faktor eksogen seperti kondisi sosial masyarakat, peraturan - peraturan dan kondisi fisik alam. Keputusan yang diambil akan menciptakan interaksi antar aktor sehingga menghasilkan outcome yang akan berdampak pada implementasi kebijakan. interaksi antar aktor tidak dapat dilepaskan dari peraturan yang mengikat sehingga interaksi antar peraturan juga perlu mendapat perhatian karena menjadi faktor eksogen yang sangat berpengaruh disamping faktor lainnya. Interaksi antar aktor dan outcome yang dihasilkan serta interaksi antar peraturan itulah yang akan menjadi fokus pembahasan dalam rangka identifikasi permasalahan kelembagaan yang menyebabkan tidak optimalnya penerapan peraturan kewajiban penyediaan parkir bagi mobil baru di Provinsi DKI Jakarta.

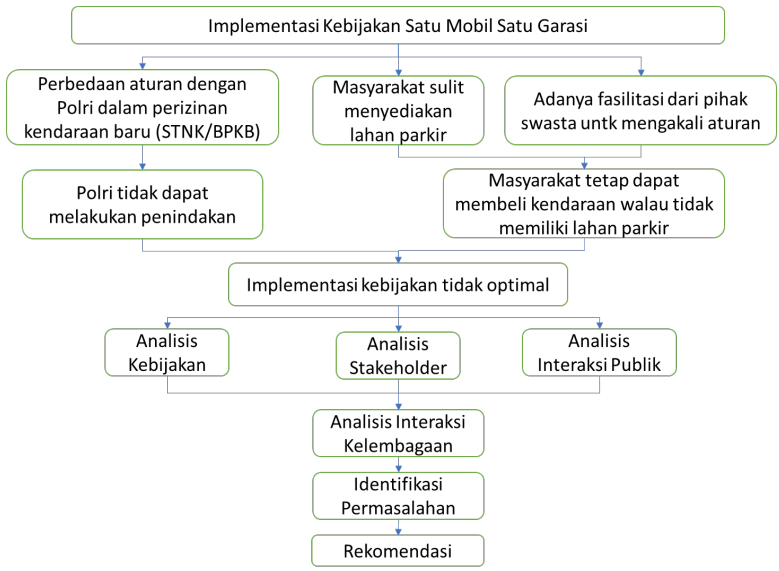

Gambar 2. Kerangka Pikir (Peneliti, 2021)

\section{HASIL DAN PEMBAHASAN}

3.1. Kebijakan Satu Mobil Satu Garasi pada Perda Provinsi DKI Jakarta Nomor 5 Tahun 2014 tentang Transportasi

Kebijakan satu mobil satu garasi memaksa setiap orang yang akan membeli kendaraan wajib menyerahkan bukti kepemilikan garasi dari kelurahan setempat dan di izinkan untuk membeli kendaraan. Jika, kriteria tersebut tidak dipenuhi maka masyarakat tidak dapat memiliki kendaraan. Jadi, untuk mengurus STNK perlu adanya bukti kepemilikan garasi. Tetapi, pada Undang-Undang Nomor 22 Tahun 2009 tentang Lalu Lintas dan Angkutan Umum untuk kepemilikan kendaraan bermotor peraturan hanya faktur kendaraan, cek fisik, dan KTP.

Realitanya, peraturan daerah dengan keadaan saat ini masyarakat untuk dapat membeli kendaraan bermotor menyerahkan bukti kepemilikan lahan parkir. Tetapi, kepemilikan lahan parkir dapat dimanipulasi karena tidak adanya pengawasan dari showroom/leasing. Sehingga, hal ini membuat masyarakat tidak berfikir kembali untuk membeli kendaraan lagi. Jika hal ni dibiarkan akan mengakibatkan meningkatnya jumlah kendaraan bermotor di jalanan. Selain itu, lahan parkir di ruang jalan dipergunakan untuk parkir kendaraan bermotor sehingga menghambat lalu lintas. Peraturan Daerah nomor 5 tahun 2014 dengan Undang-Undang nomor 22 tahun 2009 terdapat perbedaan satu dengan lainnya. Undang-undang nomor 22 tahun 2009 tidak mendukung Peraturan Daerah nomor 5 tahun 2014. Perbedaan tersebut 
Wahjoerini, Pamurti Indonesian Journal of Spatial Planning, Vol 2, No 2, 2021, 1-10

meliputi persyaratan untuk menerbitkan STNK dan BPKB.

People/Actor, adalah pihak-pihak yang terkait dalam kelembagaan dan pelaksana dari setiap kebijakan yang telah ditetapkan (Williamson, 2000). Identifikasi aktor terkait menjadi sangat penting karena pelaksanaan seluruh kebijakan akan sangat dipengaruhi oleh kewenangan dan kepentingan antar aktor. Identifikasi terhadap seluruh aktor terkait implementasi Perda DKI Jakarta nomor 5 tahun 2014 menjadi sangat penting mengingat dampak kebijakan yang sangat luas dan melibatkan banyak pihak. Identifikasi aktor tersebut juga akan membantu mengidentifikasi kemungkinan adanya konflik kepentingan antar aktor. Berikut adalah identifikasi aktor terkait implementasi Perda DKI Jakarta nomor 5 tahun 2014:

Tabel 1. Aktor terkait Implementasi Kebijakan Satu Mobil Satu Garasi (hasil analisis, 2021)

\begin{tabular}{|c|c|c|}
\hline \multicolumn{2}{|c|}{ Aktor Terkait } & Peran \\
\hline \multirow[t]{3}{*}{$\begin{array}{l}\text { Pemerintah } \\
\text { Pusat }\end{array}$} & $\begin{array}{l}\text { Kementerian } \\
\text { Perhubungan }\end{array}$ & $\begin{array}{l}\text { Regulator } \\
\text { transportasi di } \\
\text { tingkat nasional }\end{array}$ \\
\hline & $\begin{array}{l}\text { Kepolisian } \\
\text { Republik } \\
\text { Indonesia }\end{array}$ & $\begin{array}{l}\text { Penerbit STNK } \\
\text { dan BPKB }\end{array}$ \\
\hline & $\begin{array}{l}\text { Kementerian } \\
\text { Perindustrian }\end{array}$ & $\begin{array}{l}\text { Regulator } \\
\text { industri di tingkat } \\
\text { nasional }\end{array}$ \\
\hline \multirow[t]{5}{*}{$\begin{array}{l}\text { Pemerintah } \\
\text { Provinsi } \\
\text { DKI } \\
\text { Jakarta }\end{array}$} & $\begin{array}{l}\text { Dinas } \\
\text { Perhubungan } \\
\text { dan } \\
\text { Transportasi }\end{array}$ & $\begin{array}{l}\text { Pelaksana } \\
\text { Perda nomor } 5 \\
\text { tahun } 2014\end{array}$ \\
\hline & $\begin{array}{l}\text { Satuan Polisi } \\
\text { Pamong } \\
\text { Praja }\end{array}$ & $\begin{array}{l}\text { Penegak aturan } \\
\text { dalam lingkup } \\
\text { Pemerintah } \\
\text { Daerah }\end{array}$ \\
\hline & $\begin{array}{l}\text { Dinas Cipta } \\
\text { Karya, Tata } \\
\text { Ruang dan } \\
\text { Permukiman }\end{array}$ & $\begin{array}{l}\text { Perencana Tata } \\
\text { Ruang yang di } \\
\text { dalamnya terkait } \\
\text { lokasi parkir }\end{array}$ \\
\hline & BPKAD & $\begin{array}{l}\text { Mengatur pajak } \\
\text { kendaraan } \\
\text { bermotor }\end{array}$ \\
\hline & Kelurahan & $\begin{array}{l}\text { Mengeluarkan } \\
\text { surat bukti } \\
\text { kepemilikan } \\
\text { garasi }\end{array}$ \\
\hline
\end{tabular}

\begin{tabular}{|c|c|c|}
\hline \multicolumn{2}{|c|}{ Aktor Terkait } & Peran \\
\hline \multicolumn{2}{|c|}{ Swasta (Dealer/Leasing) } & $\begin{array}{l}\text { menjual } \\
\text { kendaraan } \\
\text { bermotor }\end{array}$ \\
\hline \multirow[t]{2}{*}{$\begin{array}{l}\text { Masyarakat } \\
\text { Umum }\end{array}$} & Pro Perda & $\begin{array}{l}\text { Objek } \\
\text { pelaksanaan } \\
\text { Perda nomor } 5 \\
\text { tahun } 2014\end{array}$ \\
\hline & Kontra Perda & $\begin{array}{l}\text { Objek } \\
\text { pelaksanaan } \\
\text { Perda nomor } 5 \\
\text { tahun } 2015\end{array}$ \\
\hline \multicolumn{2}{|c|}{ Aktor Terkait } & Peran \\
\hline \multirow[t]{3}{*}{$\begin{array}{l}\text { Pemerintah } \\
\text { Pusat }\end{array}$} & $\begin{array}{l}\text { Kementerian } \\
\text { Perhubungan }\end{array}$ & $\begin{array}{l}\text { Regulator } \\
\text { transportasi di } \\
\text { tingkat nasional }\end{array}$ \\
\hline & $\begin{array}{l}\text { Kepolisian } \\
\text { Republik } \\
\text { Indonesia }\end{array}$ & $\begin{array}{l}\text { Penerbit STNK } \\
\text { dan BPKB }\end{array}$ \\
\hline & $\begin{array}{l}\text { Kementerian } \\
\text { Perindustrian }\end{array}$ & $\begin{array}{l}\text { Regulator } \\
\text { industri di tingkat } \\
\text { nasional }\end{array}$ \\
\hline \multirow[t]{5}{*}{$\begin{array}{l}\text { Pemerintah } \\
\text { Provinsi } \\
\text { DKI } \\
\text { Jakarta }\end{array}$} & $\begin{array}{l}\text { Dinas } \\
\text { Perhubungan } \\
\text { dan } \\
\text { Transportasi }\end{array}$ & $\begin{array}{l}\text { Pelaksana } \\
\text { Perda nomor } 5 \\
\text { tahun } 2014\end{array}$ \\
\hline & $\begin{array}{l}\text { Satuan Polisi } \\
\text { Pamong } \\
\text { Praja }\end{array}$ & $\begin{array}{l}\text { Penegak aturan } \\
\text { dalam lingkup } \\
\text { Pemerintah } \\
\text { Daerah }\end{array}$ \\
\hline & $\begin{array}{l}\text { Dinas Cipta } \\
\text { Karya, Tata } \\
\text { Ruang dan } \\
\text { Permukiman }\end{array}$ & $\begin{array}{l}\text { Perencana Tata } \\
\text { Ruang yang di } \\
\text { dalamnya terkait } \\
\text { lokasi parkir }\end{array}$ \\
\hline & BPKAD & $\begin{array}{l}\text { Mengatur pajak } \\
\text { kendaraan } \\
\text { bermotor }\end{array}$ \\
\hline & Kelurahan & $\begin{array}{l}\text { Mengeluarkan } \\
\text { surat bukti } \\
\text { kepemilikan } \\
\text { garasi }\end{array}$ \\
\hline \multicolumn{2}{|c|}{ Swasta (Dealer/Leasing) } & $\begin{array}{l}\text { menjual } \\
\text { kendaraan } \\
\text { bermotor }\end{array}$ \\
\hline \multirow[t]{2}{*}{$\begin{array}{l}\text { Masyarakat } \\
\text { Umum }\end{array}$} & Pro Perda & $\begin{array}{l}\text { Objek } \\
\text { pelaksanaan } \\
\text { Perda nomor } 5 \\
\text { tahun } 2014\end{array}$ \\
\hline & Kontra Perda & $\begin{array}{l}\text { Objek } \\
\text { pelaksanaan } \\
\text { Perda nomor } 5 \\
\text { tahun } 2015\end{array}$ \\
\hline
\end{tabular}

\subsection{Analisis Kebijakan}

Kebijakan satu mobil satu garasi adalah kebijakan publik yang perlu dikaji lebih lanjut. 
Pendalaman ini dimaksudkan untuk melihat peraturan lain yang terkait serta interaksinya baik secara vertikal dengan peraturan pada tingkat pemerintahan diatasnya ataupun secara horizontal dengan kebijakan lain yang dikeluarkan oleh Pemerintah Provinsi DKI Jakarta. Analisis ini diperlukan untuk membandingkan antara satu kebijakan dengan kebijakan lain untuk mengidentifikasi permasalahan - permasalahan yang muncul karena perbedaan aturan.

Tabel 2. Kebijakan Satu Mobil Satu Garasi dan Peraturan Lain secara Vertikal (hasil analisis, 2021)

\begin{tabular}{|c|c|c|c|}
\hline No & Peraturan & $\begin{array}{l}\text { Isi tentang } \\
\text { Peraturan }\end{array}$ & Keterangan \\
\hline 1 & $\begin{array}{l}\text { Peraturan } \\
\text { Daerah } \\
\text { Provinsi } \\
\text { Daerah } \\
\text { Khusus } \\
\text { Ibu Kota } \\
\text { Jakarta } \\
\text { Nomor } 5 \\
\text { Tahun } \\
2014 \\
\text { Tentang } \\
\text { Transport } \\
\text { asi }\end{array}$ & $\begin{array}{l}\text { - Pasal } 140 \\
\text { ayat } 1 \text { setiap } \\
\text { orang atau } \\
\text { badan } \\
\text { usaha } \\
\text { pemilik } \\
\text { kendaraan } \\
\text { bermotor } \\
\text { wajib } \\
\text { memiliki } \\
\text { atau } \\
\text { menguasai } \\
\text { garasi } \\
\text { - Pasal } 140 \\
\text { ayat } 2 \\
\text { Setiap orang } \\
\text { atau badan } \\
\text { usaha } \\
\text { pemilik } \\
\text { kendaraan } \\
\text { bermotor } \\
\text { dilarang } \\
\text { menyimpan } \\
\text { kendaraan } \\
\text { bermotor di } \\
\text { ruang milik } \\
\text { jalan } \\
\text { Pasal } 140 \\
\text { ayat } 4 \text { Surat } \\
\text { bukti } \\
\text { kepemilikan } \\
\text { garasi } \\
\text { sebagaiman } \\
\text { a dimaksud } \\
\text { pada ayat } \\
\text { (3) menjadi } \\
\text { svarat }\end{array}$ & \\
\hline
\end{tabular}

\begin{tabular}{|c|c|c|c|}
\hline No & Peraturan & $\begin{array}{l}\text { Isi tentang } \\
\text { Peraturan }\end{array}$ & Keterangan \\
\hline & & $\begin{array}{l}\text { penertiban } \\
\text { STNK }\end{array}$ & \\
\hline 2 & $\begin{array}{l}\text { UU No } 22 \\
\text { Tahun } \\
2009\end{array}$ & $\begin{array}{l}\text { - Pasal } 68 \\
\text { ayat } 1 \\
\text { menyatakan } \\
\text { bahwa } \\
\text { Setiap } \\
\text { Kendaraan } \\
\text { Bermotor } \\
\text { yang } \\
\text { dioperasikan } \\
\text { di Jalan } \\
\text { wajib } \\
\text { dilengkapi } \\
\text { dengan } \\
\text { Surat Tanda } \\
\text { Nomor } \\
\text { Kendaraan } \\
\text { Bermotor } \\
\text { dan Tanda } \\
\text { Nomor } \\
\text { Kendaraan } \\
\text { Bermotor. }\end{array}$ & $\begin{array}{l}\text { - Dalam } \\
\text { undang - } \\
\text { undang } \\
\text { menyataka } \\
\text { n bahwa } \\
\text { setiap } \\
\text { kendaraan } \\
\text { bermotor } \\
\text { wajib } \\
\text { memiliki } \\
\text { STNK, jika } \\
\text { dikaitkan } \\
\text { dengan } \\
\text { kebijakan } \\
\text { nomer } 5 \\
\text { tentang } \\
\text { pembuatan } \\
\text { STNK tidak } \\
\text { adanya } \\
\text { kewajiban } \\
\text { harus } \\
\text { memiliki } \\
\text { garasi. Hal } \\
\text { ini secara } \\
\text { tersirat } \\
\text { bahwa } \\
\text { kebijakan } \\
\text { nomer satu } \\
\text { tidak } \\
\text { sejalan } \\
\text { dengan } \\
\text { Undang - } \\
\text { undang } \\
\text { atau } \\
\text { kebijakan } \\
\text { diatasnya. }\end{array}$ \\
\hline 3 & $\begin{array}{l}\text { Peraturan } \\
\text { Pemerinta } \\
\text { h nomor } \\
43 \text { tahun } \\
1993\end{array}$ & $\begin{array}{l}\text { - Pasal } 66 \\
\text { ayat } 1 \\
\text { Setiap jalan } \\
\text { dapat } \\
\text { dipergunaka } \\
\text { n sebagai } \\
\text { tempat } \\
\text { berhenti } \\
\text { atau parkir } \\
\text { serta } \\
\text { menyimpan } \\
\text { kendaraan } \\
\text { bermotor } \\
\text { apabila tidak } \\
\text { dilarang oleh } \\
\text { rambu- } \\
\text { rambu atau }\end{array}$ & $\begin{array}{l}\text { - Jika } \\
\text { dikaitkan } \\
\text { dengan } \\
\text { kebijakan } \\
\text { nomer satu } \\
\text { pasal } 140 \\
\text { ayat } 2 \\
\text { bahwa } \\
\text { kebijakan } \\
\text { tersebut } \\
\text { tidak } \\
\text { mendukun } \\
\text { g kebijakan } \\
\text { diatasnya } \\
\text { bahwa } \\
\text { setiap jalan } \\
\text { dapat }\end{array}$ \\
\hline
\end{tabular}


Wahjoerini, Pamurti Indonesian Journal of Spatial Planning, Vol 2, No 2, 2021, 1-10

\begin{tabular}{|c|c|c|c|}
\hline No & Peraturan & $\begin{array}{l}\text { Isi tentang } \\
\text { Peraturan }\end{array}$ & Keterangan \\
\hline & & $\begin{array}{l}\text { marka atau } \\
\text { tanda - } \\
\text { tanda lain } \\
\text { atau di } \\
\text { tempat - } \\
\text { tempat } \\
\text { tertentu }\end{array}$ & $\begin{array}{l}\text { diperhguna } \\
\text { kan } \\
\text { sebagai } \\
\text { tempat } \\
\text { berhenti } \\
\text { atau } \\
\text { menyimpa } \\
\mathrm{n} \\
\text { kendaraan } \\
\text { bermotor. } \\
\text { Sehingga } \\
\text { kendaraan } \\
\text { bermotor } \\
\text { khusus nya } \\
\text { mobil tidak } \\
\text { perlu } \\
\text { diadakann } \\
\text { ya di } \\
\text { garasi } \\
\text { cukup } \\
\text { diletakkan } \\
\text { di setiap } \\
\text { jenis jalan } \\
\text { yang tidak } \\
\text { dilarang } \\
\text { oleh rabu - } \\
\text { rambu atau } \\
\text { marka. }\end{array}$ \\
\hline 4 & $\begin{array}{l}\text { Permenpri } \\
\text { n No 61/ } \\
\text { M - IND/ } \\
\text { PER/ 8/ } \\
2015 \text { ayat } \\
5\end{array}$ & $\begin{array}{l}\text { - Pasal } 8 \text { ayat } \\
5 \\
\text { Perusahaan } \\
\text { industri } \\
\text { kendaraan } \\
\text { bermotor } \\
\text { roda empat/ } \\
\text { lebih dan } \\
\text { perusahaan } \\
\text { industri } \\
\text { sepeda } \\
\text { motor yang } \\
\text { melakukan } \\
\text { penambaha } \\
\text { n rencana } \\
\text { produksi }\end{array}$ & $\begin{array}{l}\text { - Jika } \\
\text { dikaitkan } \\
\text { dengan } \\
\text { kebijakan } \\
\text { nomer satu } \\
\text { pasal } 140 \\
\text { ayat } 1 \text { hal } \\
\text { ini tidak } \\
\text { berbanding } \\
\text { lurus, } \\
\text { dimana } \\
\text { kebijakan } \\
\text { pertama } \\
\text { tidak } \\
\text { mendukun } \\
\text { g terhadap } \\
\text { penambah } \\
\text { an rencana } \\
\text { produksi } \\
\text { perusahaa } \\
\text { n industri } \\
\text { kendaraan } \\
\text { bermotor } \\
\text { roda } 4 \text { atau } \\
\text { lebih }\end{array}$ \\
\hline 5 & $\begin{array}{l}\text { Peraturan } \\
\text { Kapolri }\end{array}$ & $\begin{array}{l}\text { - Pasal } 37 \\
\text { ayat } 2 \text { STNK }\end{array}$ & $\begin{array}{l}\text { - Apabila } \\
\text { dikaitkan }\end{array}$ \\
\hline
\end{tabular}

\begin{tabular}{|c|c|c|c|}
\hline No & Peraturan & $\begin{array}{l}\text { Isi tentang } \\
\text { Peraturan }\end{array}$ & Keterangan \\
\hline & $\begin{array}{l}\text { Nomor } 5 \\
\text { Tahun } \\
2012 \\
\text { Tentang } \\
\text { Registrasi } \\
\text { dan } \\
\text { Identifikasi } \\
\text { Kendaraa } \\
\text { n } \\
\text { Bermotor }\end{array}$ & $\begin{array}{l}\text { berfungsi } \\
\text { sebagai } \\
\text { bukti } \\
\text { legitimasi } \\
\text { pengoperasi } \\
\text { an ranmor } \\
\text { - Pasal } 79 \\
\text { ayat ayat } 1 \\
\text { menyatakan } \\
\text { bahwa } \\
\text { penertiban } \\
\text { STNK terdiri } \\
\text { atas : } \\
\text { 1. Mengisi } \\
\text { formulir } \\
\text { permoh } \\
\text { onan; } \\
\text { 2. Melamp } \\
\text { irkan } \\
\text { tanda } \\
\text { bukti } \\
\text { identita } \\
\text { s } \\
\text { kepend } \\
\text { udukan } \\
\text { atau } \\
\text { KTP }\end{array}$ & $\begin{array}{l}\text { kebijakan } \\
\text { nomer satu } \\
\text { pasal } 140 \\
\text { ayat } 3 \\
\text { bahwa } \\
\text { penertiban } \\
\text { garasi } \\
\text { termasuk } \\
\text { kepemilika } \\
\text { n STNK, } \\
\text { tidak } \\
\text { sejalan } \\
\text { dengan } \\
\text { peraturan } \\
\text { kapolri } \\
\text { dimana } \\
\text { STNK } \\
\text { sebagai } \\
\text { bukti } \\
\text { legitimasi } \\
\text { pengopera } \\
\text { sian } \\
\text { ranmor } \\
\text { bukan } \\
\text { penertiban } \\
\text { pengadaan } \\
\text { garasi. }\end{array}$ \\
\hline
\end{tabular}

Dari tabel diatas dapat diketahui bahwa kebijakan terkait kepemilikan garasi bagi pemilik kendaraan bermotor khusus nya mobil terdapat tumpang tindih dengan kebijakan yang kedudukannnya diatasnya yang saling terkait, antara lain:

- Pada Perda Provinsi DKI Jakarta Nomor 5 Tahun 2014 menyatakan bahwa penertiban garasi termasuk dalam penertiban STNK, sedangkan dalam peraturan Kapolri Nomor 5 Tahun 2012 yang memiliki wewenang dalam menertibkan STNK, menyebutkan dalam penertiban STNK hanya dipelrukan formulir penertiban dan kartu idenitas.

- Pada peraturan Permenprin No 61/ M - IND/ PER/ 8/ 2015 ayat 5 menyatakan bahwa perusahaan industri kendaraan bermotor khususnya mobil melakukan penambahan rencana produksi setiap tahunnya, hal ini di mendukung kebijakan Perda Provinsi DKI Jakarta Nomor 5 Tahun 2014 dengan tujuan untuk mengurangi kendaraan bermotor di Provinsi DKI Jakarta. 
Tabel 3. Kebijakan Satu Mobil Satu Garasi dan Peraturan Lain secara Horizontal (hasil analisis, 2021)

\begin{tabular}{|c|c|c|c|}
\hline No & $\begin{array}{c}\text { Peratura } \\
\mathbf{n}\end{array}$ & $\begin{array}{l}\text { Isi tentang } \\
\text { Peraturan }\end{array}$ & Keterangan \\
\hline 1 & $\begin{array}{l}\text { Peraturan } \\
\text { Daerah } \\
\text { Provinsi } \\
\text { Daerah } \\
\text { Khusus } \\
\text { lbu Kota } \\
\text { Jakarta } \\
\text { Nomor } 5 \\
\text { Tahun } \\
2014 \\
\text { Tentang } \\
\text { Transport } \\
\text { asi }\end{array}$ & $\begin{array}{l}\text { - Pasal } 140 \\
\text { ayat } 1 \text { setiap } \\
\text { orang atau } \\
\text { badan usaha } \\
\text { pemilik } \\
\text { kendaraan } \\
\text { bermotor } \\
\text { wajib memiliki } \\
\text { atau } \\
\text { menguasai } \\
\text { garasi } \\
\text { Pasal } 140 \\
\text { ayat } 2 \\
\text { Setiap orang } \\
\text { atau badan } \\
\text { usaha pemilik } \\
\text { kendaraan } \\
\text { bermotor } \\
\text { dilarang } \\
\text { menyimpan } \\
\text { kendaraan } \\
\text { bermotor di } \\
\text { ruang milik } \\
\text { jalan } \\
\text { Pasal } 140 \\
\text { ayat } 4 \text { Surat } \\
\text { bukti } \\
\text { kepemilikan } \\
\text { garasi } \\
\text { sebagaimana } \\
\text { dimaksud } \\
\text { pada ayat (3) } \\
\text { menjadi } \\
\text { syarat } \\
\text { penertiban } \\
\text { STNK }\end{array}$ & \\
\hline 2 & $\begin{array}{l}\text { Peraturan } \\
\text { Daerah } \\
\text { Provinsi } \\
\text { Daerah } \\
\text { Khusus } \\
\text { Ibu Kota } \\
\text { Jakarta } \\
\text { Nomor } 5 \\
\text { Tahun } \\
2012 \\
\text { Tentang } \\
\text { Perpakira } \\
\text { n }\end{array}$ & $\begin{array}{l}\text { - Pasal } 11 \text { ayat } \\
\text { (1) } \\
\text { Penggunaan } \\
\text { ruang milik } \\
\text { jalan untuk } \\
\text { fasilitas parkir } \\
\text { hanya dapat } \\
\text { diselenggarak } \\
\text { an di jalan } \\
\text { kolektor dan } \\
\text { jalan lokal } \\
\text { berdasarkan } \\
\text { kawasan } \\
\text { (zoning) }\end{array}$ & $\begin{array}{l}\text { - Jika } \\
\text { dikaitkan } \\
\text { dengan } \\
\text { kebijakan } \\
\text { nomer } 1 \\
\text { bisa } \\
\text { dikatakan } \\
\text { bahwa } \\
\text { tidak } \\
\text { adanya } \\
\text { keselaras } \\
\text { an. } \\
\text { Kendaraa } \\
\mathrm{n} \\
\end{array}$ \\
\hline
\end{tabular}

\begin{tabular}{|l|l|l|l|}
\hline No & $\begin{array}{c}\text { Peratura } \\
\mathbf{n}\end{array}$ & $\begin{array}{c}\text { Isi tentang } \\
\text { Peraturan }\end{array}$ & Keterangan \\
\hline & & pengendalian & bermotor \\
& & parkir. & dapat \\
& & & berpakir di \\
& & & jalan \\
& & & kolektor \\
& & & dan jalan \\
& & & lokal. \\
\hline
\end{tabular}

Dari tabel diatas dapat diketahui bahwa kebijakan terkait kepemilikan garasi bagi pemilik kendaraan bermotor khusus nya mobil terdapat tumpang tindih dengan kebijakan yang kedudukannnya yang setara dan saling terkait, antara lain pada Perda Provinsi Jakarta tentang perpakiran menunjukkan bahwa jalan kolektor dan jalan lokal dapat digunakan parkir. Sedangkan pemahaman masyarakat saat ini, bahwa jalan lokal khususnya tidak hanya sebagai tempat parkir namun sebagai tempat penyimpanan mobil mereka bagi yang tidak memiliki garasi sebagai tempat penyimpanan.

\subsection{Analisis Stakeholder}

Analisis ini bermaksud untuk mengidentifikasi interaksi antar aktor terkait kepentingan dan kewenangannya serta konflik konflik yang mungkin terjadi. Konflik antar aktor sangat mungkin terjadi karena banyak kasus membuktikan bahwa hambatan terbesar dalam implementasi suatu kebijakan adalah adanya perbedaan kepentingan antar aktor. Perbedaan ini dapat disebabkan oleh faktor regulasi, ekonomi ataupun sosial masyarakat. Berdasarkan identifikasi aktor yang telah dilakukan sebelumnya, maka dilakukan identifikasi kepentingan dan kewenangan antar aktor dan memetakannya. Berikut adalah identifikasi kepentingan dan kewenangan antar aktor:

kepentingan dan kewengan masing-masing aktor dipetakan dalam kuadran kewenangan dan kepentingan berdasarkan PMBOK $5^{\text {th }}$ Edition (Project Management Institute, 2013). 


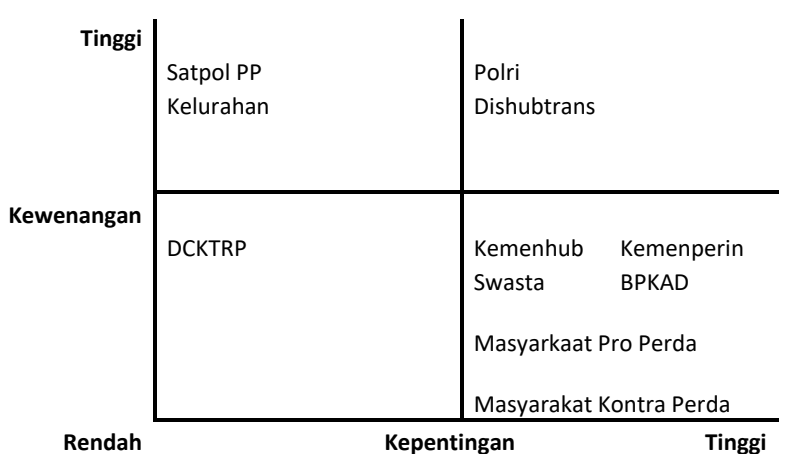

Gambar 3. Analisis Stakeholder dalam Implementasi Kebijakan Satu Mobil Satu Garasi (Peneliti, 2021)

Gambar diatas memperlihatkan bahwa terdapat kemungkinan terjadinya konflik kepentingan antar aktor terkait implementasi sementara itu jika dirinci lebih lanjut, terdapat kemungkinan konflik kepentingan dan potensi yang dapat dikembangkan melalui interaksi antar aktor.

\subsection{Analisis Interaksi Kelembagaan}

Berdasarkan analisis yang telah dilakukan sebelumnya yaitu analisis kebijakan dan analisis stakeholder, diketahui potensi dan permasalahan dalam implementasi kebijakan satu mobil satu garasi. Permasalahan tersebut tidak dapat dibahas sebagai bagian yang saling terpisah namun memiliki keterkaitan satu dengan lainnya. Pohon masalah adalah satu diantara metode untuk mengkaji permasalahan secara lebih terstruktur

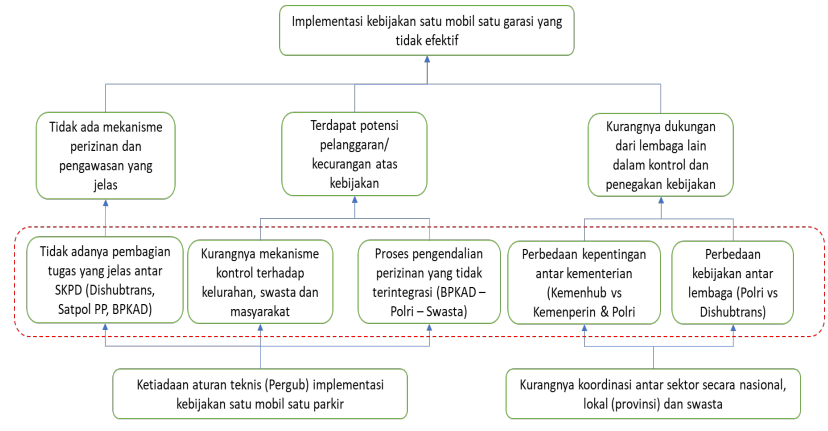

Gambar 4. Pohon Masalah Implementasi Kebijakan Satu Mobil Satu Garasi (Peneliti, 2021)

Gambar diatas memperlihatkan bahwa masalah yang ada berakar dari ketiadaan aturan teknis dan kurangnya koordinasi antar sektor pemerintahan baik dalam skala nasional maupun lokal (provinsi). Kedua akar masalah tersebut menghasilkan permasalahan yang terjadi saat ini seperti perbedaan peraturan dan kepentingan antar Lembaga. Kemudian belum adanya mekanisme kontrol perizinan dan pengawasan yang terstruktur dan terintegrasi antar Lembaga. Permasalahan yang terjadi antar aktor juga dipengaruhi oleh peraturan yang menaunginya. Polri tidak dapat memasukan kepemilikan garasi sebagai syarat penerbitan STNK dan BPKB karena tidak tercantum dalam Peraturan Kapolri Nomor 5 Tahun 2012 Tentang Registrasi dan Identifikasi Kendaraan Bermotor. Begitu pula dengan kebijakan satu mobil satu garasi yang cenderung kontradiktif dengan target Kementerian Perindustrian yang tertuang dalam Permenprin No 61/ M - IND/ PER/ 8/ 2015 ayat 5 . Konflik antar aktor juga terjadi karena perbedaan kepentingan. Polri membutuhkan penerbitan STNK dan BPKB yang menjadi sumber pemasukan negara melalui PNBP. Sementara itu BPKAD membutuhkan pajak mobil baru untuk menambah PAD. Perbedaan kepentingan ini membuat antar lembaga tidak dapat saling berkoordinasi. Masalah - masalah tersebut pada akhirnya mengakibatkan implementasi kebijakan satu mobil satu garasi tidak dapat maksimal.

Tabel 4. Pemetaan Permasalahan (hasil analisis, 2021)

\begin{tabular}{|c|c|c|c|c|}
\hline & \multicolumn{4}{|c|}{ Elemen Kelembagaan } \\
\hline & & Function(s) & Enabler(s) & Actor(s) \\
\hline \multirow{4}{*}{ 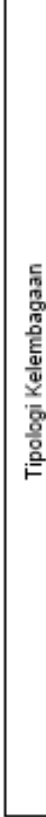 } & $\begin{array}{l}\text { Informal } \\
\text { institution }\end{array}$ & & & $\begin{array}{l}\text { Masyarakat yang } \\
\text { cenderung suka } \\
\text { melanggar aturan }\end{array}$ \\
\hline & $\begin{array}{l}\text { Formal } \\
\text { Institution }\end{array}$ & $\begin{array}{l}\text { Peraturan } \\
\text { Polri yang } \\
\text { tidak } \\
\text { mengakomodir } \\
\text { kewajiban } \\
\text { pemilikan } \\
\text { garasi }\end{array}$ & $\begin{array}{l}\text { Perbedaan } \\
\text { peraturan } \\
\text { terkait izin } \\
\text { kendaraan } \\
\text { dan } \\
\text { keberadaan } \\
\text { garasi } \\
\text { (Perda } \\
\text { nomor } 5 \\
\text { tahun } 2014 \\
\text { dengan } \\
\text { Perkap } \\
\text { nomor } 5 \\
\text { tahun 2012 } \\
\text { dan PP } \\
\text { nomor 43 } \\
\text { tahun 1993) }\end{array}$ & $\begin{array}{l}\text { Kemenhub vs } \\
\text { Polri, Kemenhub } \\
\text { vs Kemenperin }\end{array}$ \\
\hline & $\begin{array}{l}\text { Governance } \\
\text { Institution }\end{array}$ & $\begin{array}{l}\text { Tidak ada } \\
\text { peraturan } \\
\text { yang membagi } \\
\text { tugas dan } \\
\text { wewenang } \\
\text { antar lembaga }\end{array}$ & $\begin{array}{l}\text { Ketiadaan } \\
\text { aturan teknis } \\
\text { implementasi } \\
\text { kebijakan } \\
\text { (pergub) }\end{array}$ & $\begin{array}{l}\text { Dishubtrans vs } \\
\text { BPKAD }\end{array}$ \\
\hline & $\begin{array}{l}\text { Resource } \\
\text { Allocation }\end{array}$ & & & $\begin{array}{l}\text { Tidak ada } \\
\text { perizinan yang } \\
\text { terintegrasi antar } \\
\text { lembaga } \\
\text { (BPKAD, Polri, } \\
\text { Dishubtrans }\end{array}$ \\
\hline
\end{tabular}


Selain permasalahan diatas, juga terdapat potensi yang dapat dimanfaatkan dalam implementasi kebijakan satu mobil satu garasi, diantaranya adalah:

a. Terdapat potensi integrasi perizinan antara Dishubtrans, Polri dan BPKAD dengan menyamakan kepentingan dan peraturan.

b. Polri dan Satpol PP dapat bertindak sebagai pengawas sekaligus melakukan penindakan jika terjadi pelanggaran, dibutuhkan peraturan khusus yang menaungi potensi ini seperti penerapan kebijakan Ganjil - Genap.

c. Pihak swasta dapat dijadikan sebagai partner dalam verifikasi kepemilikan garasi.

d. Masyarakat perlu diikutsertakan dalam pengawasan kebijakan tersebut karena masyarakat (RT/RW) dapat memantau terus menerus dan memiliki pengetahuan yang lebih mendalam terkait wilayahnya. Perlu adanya mekanisme khusus dalam pengawasan yang menyertakan masyarakat.

\section{SIMPULAN}

Dampak lain yang ditimbulkan oleh peningkatan jumlah kendaraan adalah ketersediaan lahan parkir. Terbatasnya lahan parkir membuat pemerintah setempat dituntut untuk mengatur terkait lahan parkir. Fenomena ini terjadi di Kota Jakarta, banyak dijumpai pada perumahan - perumahan dengan parkir kendaraan pribadi yang tidak tertata dengan baik sehingga menyusahkan pergerakan kendaraan yang lain jika melewati jalan tersebut, hal ini dikarenakan tidak adanya lahan parkir pada setiap rumah sehingga kendaraan pribadi khususnya mobil diparkir di depan rumah secara tidak teratur. Permasalahan tersebut memaksa pemerintah Provinsi DKI Jakarta menetapkan aturan mengenai kewajiban pemilik kendaraan bermotor harus punya garasi tertuang dalam Pasal 140 perda tentang transportasi tersebut. Namun dalam implementasinya, peraturan tersebut tidak dapat berjalan maksimal karena terdapat permasalahan - permasalahan diantaranya adalah perbedaan kebijakan baik di tingkat nasional ataupun tingkat provinsi, serta perbedaan kepentingan antar aktor.

\section{REFERENSI}

Amin, A., dan Thrift, N. (1995): Globalisation, institutional 'thickness' and the local economy", in Managing Cities: The New Urban Context, (P. Healey, S. Cameron, S. Davoudi, S. Graham, dan A. Madani-Pour, Ed.), Sussex: John Wiley \& Sons, Inc.

Arnstein, S. R. (1969): A Ladder Of Citizen Participation, Journal of the American Planning Association, 35(4), 216-224, https://doi.org/10.1080/019443669089772 25.

Asian Development Bank (2011): Parking Policy in Asian Cities, Asian Development Bank.

Clingermayer, J. C., dan Feiock, R. C. (2001): Institutional Constraints and Policy Choice: An Exploration of Local Governance, Albany: Suny Press.

Koontz, T. (2003): An introduction to the institutional analysis and development (IAD) framework for forest management research, First Nations and Sustainable Forestry: Institutional Conditions for Success, Columbus, diambil dari http://www.forestry.ubc.ca/fnconditions/_d ocuments/TomKoontzPaper.pdf.

Ostrom, E. (1990): Governing The Commons, Cambridge: Cambridge University Press.

Ostrom, E. (2005): Understanding Institutional Diversity, Princeton University Press, New Jersey: Princeton University Press, https://doi.org/10.1007/s11127-007-9157$\mathrm{x}$.

Polski, M. M., dan Ostrom, E. (1999): An Institutional Framework for Policy Analysis and Design by, Development, An Institutional Framework for Policy Analysis and Design by.pdf.

Project Management Institute (2013): A Guide to the Project Management Body of Knowledge, 5th ed., Project Management Institute.

Ruttan, V. W., dan Hayami, Y. (1984): The Journal of Development Toward a theory of induced institutional innovation, The Journal of Development Studies, (June 2014), 37-41, https://doi.org/10.1080/002203884084219 14.

Verma, N. (Ed.) (2007): Institutions and Planning, Amsterdam: Elsevier.

Williamson, O. E. (1985): The Economic 
Institutions of Capitalism: Firms, Markets , Relational Contracting, New York: Collier Macmillan Publisher.

Williamson, O. E. (2000): New Taking Institutional Economics: Ahead Looking, 38(3), 595-613. 